much value; when accumulated, however, the case is very different. Were it known that a record of any obscure or rarely observed custom would be duly filed and classified and be readily available to any one who was studying native folk-lore, the probability is that many memoranda which otherwise would be lost would find their way to the Bureau. It cannot be ton often or too strongly insisted upon, that now is the time for the collection of all anthropological data in every department of that far-reaching science. To many, results alone are interesting, and there is too frequently a danger to generalise from imperfect data. Posterity will have plenty of time in which to generalise and theorise, but it will have scarcely any opportunity for recording new facts. This century has been one of most rapid transition. The apathy of our predecessors has lost to us an immense amount of information : let not this reproach be applied to us by our descendants."

A decade ago, that distinguished Indian officer Major R. C. Temple wrote: "I have no hesitation in saying that to us Englishmen such studies are not only practical, but they are in some respects of the first importance. The practices and beliefs included under the general head of folk-lore make up the daily life of the natives of our great dependency, control their feelings, and underlie many of their actions. We foreigners cannot hope to understand them rightly unless we deeply study them, and it must be rememhered that close acquaintance and a right understanding beget sympathy, and sympathy begets good government; and who is there to say that a scientific study which promotes this, and, indeed, to some extent renders it possible, is not a practical one?"

A. C. IIADDON.

\section{INSECTS AND YEASTS.}

IN the Portici Laboratory for Agricultural Chemistry, Dr. Amedeo Berlese has been making interesting investigations on the manner in which some insects-ants and flies especially-contribute to the diffusion, preservation and multiplication of alcoholic ferments.

It had been formerly observed by Dr. Berlese that on the trunks, both of fruit and forest trees, hidden in the fissures of the bark, the cells of alcoholic yeasts (Saccharomyces apiculatus and Saccharomyces ellipsoideus) are commonly found. It was natural to suspect that ants, which are constantly travelling up and down trunks and branches, and perhaps also flies, should be among the chief agents in disseminating yeast cells on trees. Dr. Berlese had also observed that these cells are often more numerous on the sunny side of the trees, where insects, especially flies, are likely to linger.

The first series of experiments was to show that ants, starting from an infected soil, and being themselves infected with yeast cells, carry them for a distance up stems and branches, infecting the fruits which they visit, and thence travelling further may carry on the yeast-infection into a sterilised soil.

The apparatus used was very simple (Fig. I). Inside a large glass jar A, well closed and carefully sterilised, a bunch of grapes was hung, after due sterilisation by successive washing and immersion in carbon disulphide and boiling water. The jar containing the grapes communicated by means of two long glass tubes (about $1 \cdot 30 \mathrm{~m}$. each) with a glass bottle on each side. These long tubes and the bottles were also carefully sttrilised, and connected, by means of corks, so as to form, together with the central jar, a closed system, into which, how. ever, air could penetrate after filtering through sterilised cotton wool. Fourteen of these combinations were prepared, into each of which, in one of the side bottles B, non-sterilised substances were introduced, probably containing yeast cells, such as soil, bark of vines, bark of vine-poles and of oak-trees. In the second side bottle c, the same substances were introduced, but after careful sterilisation. Inside the long tubes were put slender vine branches connecting the substances in the side bottles $\mathrm{B}$ and $\mathrm{C}$ with the grapes in the central jar A. These vine branches, previously sterilised, were the paths along which the ants were to travel on their way from the infected material in $B$ to the grapes in $\mathrm{A}$, and thence onwards to the sterilised material in c. Before introducing the insects it was verified that each apparatus was internally sterile. Some apparatus were left without insects during all the time of the experiments for more

1 Rapporti fra la Vite ed i Saccaromiceti. Ricerche sui mezzi di trasporto dei Fermenti alcoolici. Amedeo Berlese. Rivista di Patologia
Vegetale e Zimologia, 1897 .

NO. I 459, voL. 56] than two months, in order to show that where no insect had been introduced the grapes remained sterile, bearing on their surface neither moulds, nor yeasts, nor bacteria.

Large numbers of ants were collected from the trunks of trees. One species-the Cremastogaster scutellaris - was preferred, because it lives in trees, and is very common on vines and vine-poles. The ants were collected with due precaution into sterilised glass vessels, and thence introduced into the bottle $\mathrm{B}$ of each apparatus, in numbers varying from a minimum of about 100 to a maximum of about 5000 . In the bottle $\mathrm{B}$ the ants remained for a few days, then gradually and guardedly ad. vanced up the sterilised branches, congregating and halting at stations on their upward way in the long tubes ; generally about two days passed before the first ants appeared on the sterilised grapes in $\mathrm{A}$; thence they passed down the second tube into the bottle $\mathrm{c}$. In this way, starting from $\mathrm{B}$, the most adventurous of the ants which reached $\mathrm{c}$, had travelled a distance of $3.20 \mathrm{~m}$., about equal to the actual height of many vines from the soil, over which ants must travel when they climb up to visit the grapes. The ants used in these experiments suffered probably from want of ventilation; they attacked the corks in efforts to escape, and congregated in great numbers near the cotton wool through which the outer air filtered. Many, however, visited the grapes in search of food, biting the surface of the berries, or absorbing the juice where these had been purposely punctured. In one apparatus where the grapes were unripe, their acid juice proved rapidly poisonous to the ants: an interesting observation, for it gives evidence in favour of the protective character

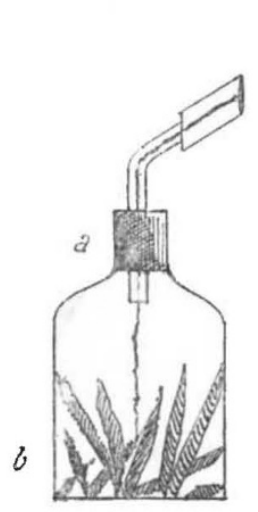

B

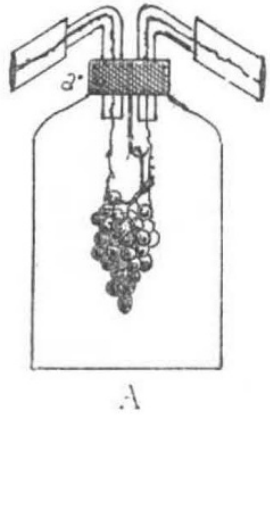

FIG. I

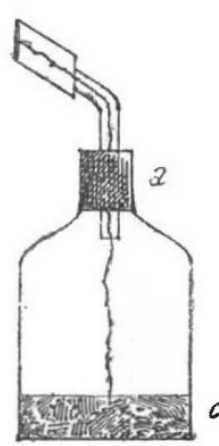

$\mathrm{C}$ of the acids existing in fruit juices before maturation. A small number of ants reached the bottle c. After ten or twelve days most of the ants were dead, and the experiments were ended. The grapes and the materials in $\mathrm{C}$, that had been previously sterilised, were now separately tested to see if through the agency of the ants they had been infected with yeasts. The grapes were removed from the jars with due caution to prevent air-infection, and after shaking off gently all insects still adhering to the fruit; whole berries or small portions of the stalks of the bunches were dropped, without delay, into test-tubes containing sterilised grape-must; and the plugged test-tubes were then left in the thermostat for several days, at a temperature favourable to alcoholic fermentation.

The results obtained are remarkable. In the ten experiments in which ants were introduced, the infection of the grapes in A, and of the material in $\mathrm{c}$, with yeasts and moulds was evident; but varied chiefly according to the various nature of the places from which the ants originally came, and also with the nature of the non-sterilised material in $\mathrm{B}$. When the ants came from a vineyard, and the material in $\mathrm{B}$ was ordinary soil or bark of vines or of vine-poles, the germs conveyed to the grapes in $\mathrm{A}$, and to the sterilised material in C, were chiefly moulds together with Saccharomyces apiculatus and ellipsoideus; S. apiculatus was far more abundant than ellipsoideus. In one case, when B contained oak bark and the ants had been collected on oak trees, the infection of the grapes and of the material in $\mathrm{C}$ showed abundance of Saccharomyces apiculatus, with some $S$. ellipsoideus and $S$. pastorianus. When the ants and the bark in $\mathrm{B}$ came from olive-trees no yeasts were observed in the 
test-tubes. Moulds were in all cases abundant. In those cases where the grapes had been left in the apparatus some days after the ants were dead, moulds developed rapidly on the grapes, and probably destroyed all the yeasts; for in the test-tube cultures moulds were abundant, and no yeasts were observed.

Many experiments were carried out by Dr. Amedeo Berlese to prove that yeasts are abundantly distributed through various kinds of flies.

Small pieces of meat, carefully sterilised by washing in sublimate solution and then in water, were exposed on a terrace, some inside a close wire net which prevented contact with insects, and others so as to favour the visits of flying insects only. Several individuals of the Sarcophaga carnaria were noticed visiting the exposed meat. After two hours' exposure to the flies, and thirteen hours' exposure to the air, the pieces of meat were dropped into test-tubes containing sterilised must, and the sediments obtained after fermentation examined for yeasts. It was found that whenever the meat had been exposed to flies, yeasts were far more abundant than when the flies had been excluded. Saccharomyces apiculatus was the yeast that appeared more abundantly disseminated by the meat-flies; far less abundant was Saccharomyces ellipsoideus. It was calculated that the quantity of yeasts carried to a piece of meat by flies in a given time is about twenty-six times the quantity that would be carried by air alone.

In other experiments, flies were made to visit grapes that had been previously carefully sterilised. The flies were attracted to the grapes by concealing near them, but so that the flies could not touch them, pieces of meat. The flies that were chiefly attracted and alighted on the grapes were Sarcophasa carnaria

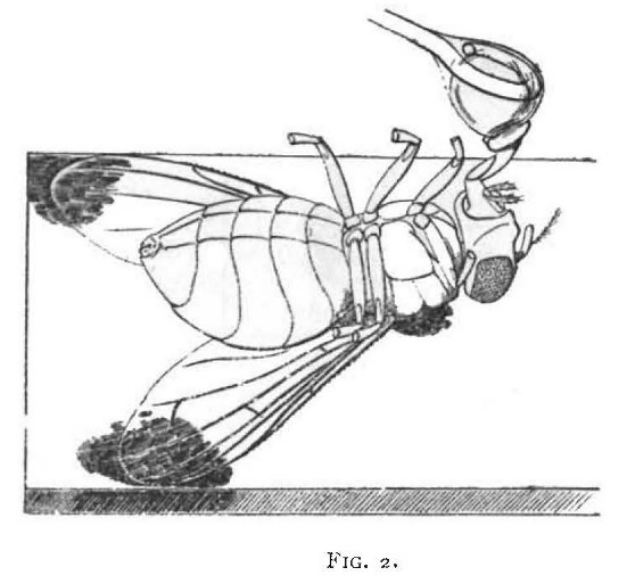

and the blue meat-fly, Calliphora erythrocephala. The grapes were found abundantly infected with Saccharomyces apiculatus, and in a far minor degree with S. ellipsoideus and S. pastorianus: moulds and Dematium were abundant. In control experiments, where flies had not been allowed to touch the grapes, these contained no yeasts. Strong infections with $S$. apiculatus were also obtained by imprisoning blue meat-flies and Sarcophaga inside a wire netting in which sterilised grapes had been hung.

On experimenting in a similar manner with the cellar-midge or vinegar-fly, the Drosophila cellaris, it was found that it conveyed in great abundance Saccharomyces ellipsoideus and pastorianus, and also in smaller quantity Saccharomyces apiculatus, besides, of course, Bacterium aceti, Dematium, and many moulds. Sterilised grapes, when visited by the cellar-midge, cause rapid fermentation of the grape-must in which they are sown.

How do winged insects convey yeasts?

Several experiments with various kinds of flies showed that ferments are often more abundant in the bodies of the flies than in their legs and feet. It is also easy to observe the presence of cells, similar to those of yeast, in the excrements of flies. Dr. Berlese was thus brought to study experimentally the passage of yeast cells through the digestive tract of meat-flies and cellar-midges.

The best experiments to prove the passage and the preservation of yeast cells inside the bodies of insects were made with meat-flies. The living flies, as shown in Fig. 2, were laid on their backs on a glass plate and pinioned there by glueing the NO. I 459 , VOL. 56] extremities of their wings to the glass; the legs of the fly thus secured were removed, in order to prevent infection of the external part of the body by the legs. The external part of the body of each fly was carefully sterilised by repeated brush washings with corrosive sublimate solution. Thus fixed on its back, externally sterilised, and secured inside a glass Petri-box, each fly was regularly fed for several days, either with sterilised grape-must, or with pure cultures of yeasts in must. The excretions of the fly were easily collected by means of a sterilised platinum loop, and examined by inoculation in sterilised must for yeast cells. This method gave full assurance that any living cell found in the excretions had passed through the intestine. The pinioned flies did not lose their desire for food, but eagerly sucked up with their proboscis the grape-must presented to them on the platinum loop, living on for several days, when kept at a temperature of from $18^{\circ}$ to $20^{\circ} \mathrm{C}$. It was observed that when the flies had been kept fasting they eagerly and completely sucked up all the yeast-laden must offered to them; but when the flies had been well fed they became more dainty, and sucked only the liquid portion of the sweet drop, leaving a residual semi-solid lump consisting largely of yeast cells; this would prove that in the act of suction with the proboscis, flies can probably at will use a filtering process to separate the solid from the liquid parts. In numerous experi-

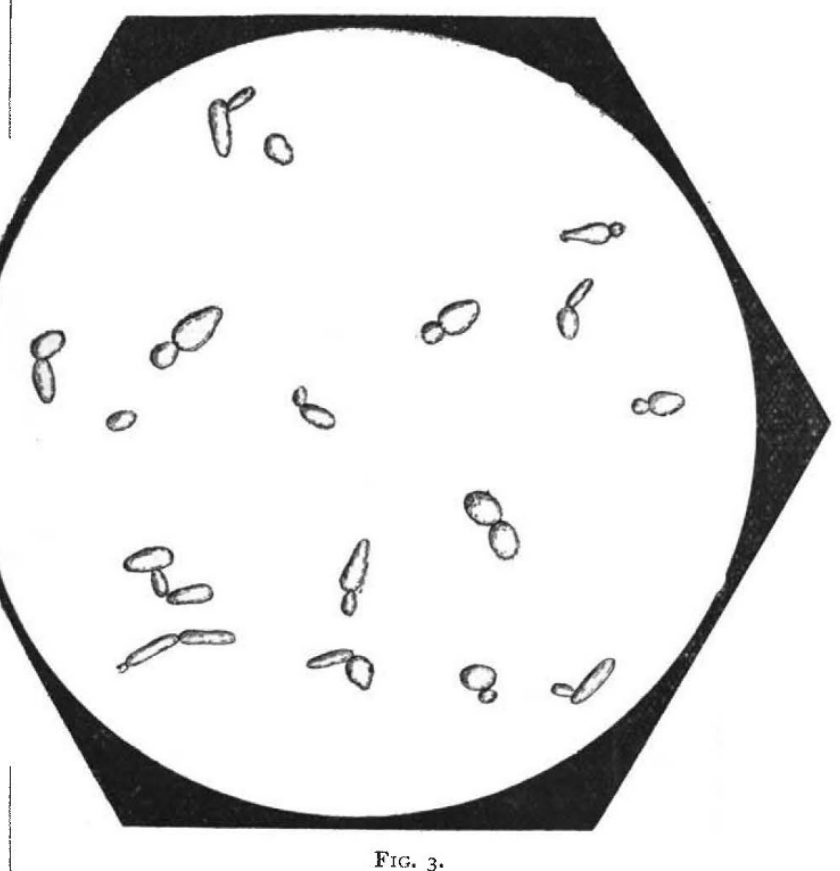

ments with blue meat-flies, flesh-flies, and cellar-midges, it was proved that when the flies are fed with sterilised must the excreta contain no yeasts, especially if gathered after repeated evacua. tions; but if, on the contrary, the flies are fed with pure cultures of Saccharomyces apiculatus, or of other yeasts, the excreta soon contain in great numbers the yeast that was in the food. The yeast cells contained in the excreta are living, for, when sown in suitable liquids, they multiply with great rapidity. Figs. 3 and 4 give an example of the multiplication, during eighteen hours, of the cells of a yeast (Saccharomy'ces pastorianus) emitted by a blue meat-fly, which had been fed with grape-must containing that yeast. The vitality of the yeast cells is also unimpaired when given to the flies with meat juice containing no sugar. The ternperatures prevailing during ingestion of yeast cells in flies influence the rapidity of their multiplication in the excreta. Thus, when Saccharomyces apiculatus is given to the flies, the cells in the excreta are in active germination when the prevailing temperature is from $20^{\circ}$ to $25^{\circ} \mathrm{C}$.; on the other hand, germinating cells are scarce if the fly has been kept at $8^{\circ}$ to $10^{\circ} \mathrm{C}$. This suggests that inside the digestive tract of the insect external conditions may influence the multiplication of the yeast cells. To prove this, some blue meat-flies were fed cnly once 
with a pure culture of Saccharomyces apiculatus, and then for the remaining days of their life with sterilised grape-must. Comparing the approximate number of cells of $S$. apiculatus originally given in the food with the great numbers of the same cells gathered successively in the excreta during several days, it was evident that the yeast cells had greatly multiplied. It was calculated that in the droplet of must containing the S. apiculatus, with which each fly was first fed, the number of yeast cells must have been about 500,000; now, continuing to feed these flies with sterilised must, the number of yeast cells expelled each time from the intestine was reckoned to be from 400,000 to 600,000 , and perhaps more. In one of these pinioned flies, that lived for eight days, the yeast cells calculated for one excretal drop on the seventh day of confinement were more than $2,500,000$; this fly, which had been fed originally with about 500,000 yeast cells, must have emitted, during the eight days in which no yeast was given to it, about $35,000,000$ cells. In some cases, especially when excretion was not frequent, the excrementitious droplet was one mass of $S$. apiculatus. There can be no doubt, therefore, that the yeast cells increase in numbers while inside the body of the insect. This was further proved by pinioning, in the manner described, some blue meat-flies just caught, feeding them exclusively with sterilised must, and examining all the excreta during the remaining days of their life ;

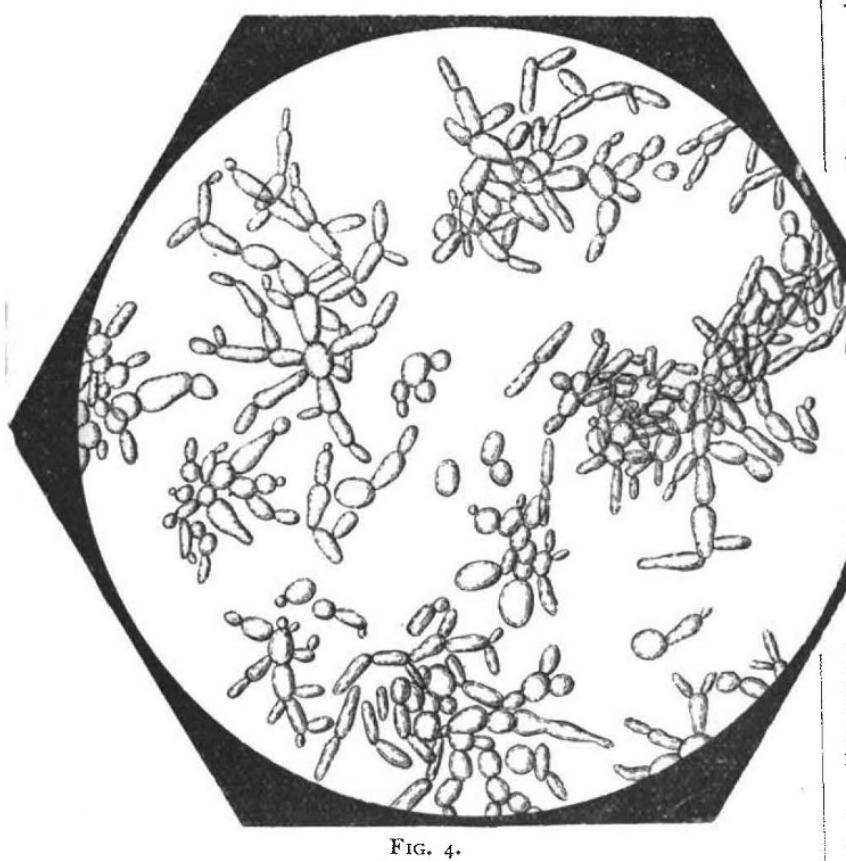

it was found that $S$. apiculatus cells, not very abundant at first, increased greatly during the succeeding days ; in these cases all the yeast cells excreted were derived from the Sacharomyces contained in the insect before captivity, gathered with its fond whilst in the free state.

On pinioning blue meat-flies in a Petri-box, and feeding them exclusively with sterilised must, $S$. apiculatus appears com. monly in the excreta, but rarely is $S$. ellipsoideus observed. This may be due both to the scarcity of $S$. ellipsoideus in the usual food of the meat-flies, and to the struggle between the various yeasts and other organisms that develop in the digestive tube. On feeding a blue meat-fly only once with a mixture of $S$. apiculatus and $S$. mycoderma, and then feeding it with sterilised must exclusively, it was observed that at first the excreta contained both the yeasts in about equal proportions; but gradually apiculatus had the upper hand on con. tinuing to feed with must; but if the insect was made to fast, the quantity of $S$. apiculatus in the excreta diminished rapidly, and those of the mycoderma greatly increased. This shows how greatly the conditions inside the intestine of the insect must influence the development of the different yeast germs.

Some observations by Drs. Amedeo and Antonio Berlese, on the internal anatomy of flies (Drosophila cellaris and common

No. I 459 . Vol. 56$]$ flies), contribute much to explain how it is that the yeasts can accumulate in great numbers and multiply inside the organism of these insects. It is known that the juices sucked up by means of the proboscis do not go directly into the intestine, but are stored up in the crop, or ingluvies, a special organ which, through a long tube, communicates with the œsophagus, at the upper part of the digestive tract. On examining the crop of many flies, it was found replete with a syrupy liquid, a concentrated sugar solution, capable of rapidly reducing Fehling's solution, in which yeast cells are observable, besides Dematium, Torula, Bacteria and ciliated infusoria. It is probable that in the sugary solution contained in the ingluvies (unless the solution be too concentrated to permit the process) the multiplication of the yeast cells must chiefly occur.

The experiments of Dr. Amedeo Berlese thus prove conclusively the great part that insects, especially ants and several kinds of flies, take, not only in the distribution (as was hitherto known), but also in the preservation and multiplication of alcoholic ferments. Insects, far more than atmospheric air, contribute to the dissemination of yeasts, wnich they convey rather internally than externally. There is, moreover, reason for believing that during the cold season some yeasts are chiefly preserved and, perhaps, increased within the organism of insects.

ITALO GIGLIOLI.

\section{TEN YEARS' WORK OF THE ROYAL} GARDENS, KEW:

THE completion of the tenth annual volume of the Kere Bu?letin has made it desirable to publish a detailed index to the whole series. As the number of volumes has increased it has become more difficult to find the information they may contain on any particular subject.

The opportunity may be taken to pass in review briefly the more important subjects which have been treated. This will have the more interest as the period covered has been one of more than usual activity in the development of our tropical possessions.

Kew, from its first establishment as a national institution in I84I, has always been applied to by men of business desirous of engaging in new industries. Response to individual inquiries gradually came to be regarded as insufficient, and a demand arose for the prompt publication for general use of any information likely to be of service to those engaged in colonial pursuits. With this object the first number of the Bulletin was issued in January 1887. But it was also intended to serve another purpose. When public attention is engaged by any particular subject, inquiries about it are numerous. To say all there is to be said about it, once for all, in the pages of the Bulletin effects a great saving in labour. To quote the prefatory notice to the first number :-

"It is hoped that while these notes will serve the purpose of an expeditious mode of communication to the numerous correspondents of Kew in distant parts of the Empire, they may also be of service to members of the general public interested in planting or agricultural business in India and the Colonies:"

On March 18, 1887, the First Commissioner of Her Majesty's Works and Public Buildings (Mr. Plunket) informed the House of Commons:-.." In response to the demands for the publication more speedily than in the annual report of information received from abroad, I have sanctioned the publication of a monthly bulletin, which can be purchased for a small sum."

Publication was originally intended to be "occasional." It has not been found practically possible to keep up an absolutely regular monthly issue. This, however, has been approached as nearly as circumstances would allow.

The original intention was to confine the Bulletin to colonial and commercial information. The suggestion of a larger scope having been raised in Parliament, especially with regard to reports on expeditions, the materials collected by which had been entrusted to Kew, to notices of interesting plants or objects received and the important plants sent out, Mr. Plunket further decided that the "Bulletin. . . should be made the vehicle of all printed matter suitable for its pages, which it is desirable to issue from Kew." As a sequel the Bulletin became, what it remains, a continuous record of Kew work in all its various aspects.

1 Reprinted from the Kerv Bulletin of Miscellaneous Information, N... ז20. 